\title{
Celia Britton, Perspectives on Culture and Politics in the French Antilles: Selected
}

Essays. Cambridge: Legenda, 2018. 147 pp. (Cloth US\$99.0o)

Celia Britton's Perspectives on Culture and Politics in the French Antilles is a collection of 12 essays, three of which have not been previously published. The writers treated cover a broad thematic and temporal range, but the bulk of the analyses concern Édouard Glissant.

The opening chapter is a detailed reading of changes in Glissant's concept of identity as seen in several of his key writings over a 30-year span. Britton emphasizes that "relations between cultures ... form identities" (p. 11) was the central feature of his thought in the 1990s, but by the mid-20oos he had gravitated toward a "relational identity [that was] the result of a relationship (a fusion) with place" (p.15). Here, she draws on a lesser-known work, Une nouvelle region du monde (2006), to illuminate the persistence of a relational identity from early to late Glissant.

Britton has long had a reputation as an expert on Glissant, and here she does not disappoint. In Chapter 5 , she focuses on the changes in perspective that bridge Le Discours antillais (1981) and Poétique de la relation (1990), a trajectory that initially claims resistance and Relation as specific to Martinique and culminates in the concept of the Tout-monde as a framework for unpredictability that "preserves the relational diversity and respect for the other" (p. 54). She then undertakes a detailed, deconstructive reading of two wellregarded analyses of Glissant's thought. First, she examines Chris Bongie's Islands and Exiles and its readings of several Glissantian novels and theoretical texts, taking issue with his conclusion that their "rejection of decolonization is a serious distortion of their overall thrust" (p. 56). Turning to Peter Hallward's Absolutely Postcolonial, she questions his conclusion that "late Glissant ... renege[s] on the author's commitment to political change" (p. 6o). Rather, as she points out, Glissant emphasizes a positional perspective that "combine[s] local action with global consciousness of Relation" (p. 61). Similarly, her reading of the obscurity of language in Glissant (Chapter 7) examines the "ruses of Creole" (p. 77) as a counter-poetics that ultimately merges with the experience of plantation slavery to generate a praxis of literary opacity aimed, somewhat paradoxically, at uncovering "not ... a hidden meaning but ... a hidden history" (p. 86). And her illuminating analysis of Glissant's novel Mahagony (1981) hinges on a revelatory reading of his innovative language use; Britton effectively demonstrates Glissant's brilliant deployment of the chronotope to establish causal links between language and place. Drawing on a key "dynamic between sameness and difference" (p. 114, emphasis in the original), she highlights the connectedness between time and space that emerges from 
his repetition of selected words to evoke different places. Ultimately, meaning is inscribed through "a whole web of intricate echoes" that demonstrates "the importance of place as textuality" (pp. 115-16).

Other fiction writers undergo similarly thorough levels of analysis. On Ernest Pépin, an intriguing reading of strategies of point of view reveals a complex rendering of Caribbean realities through his use of plural narrating subjects, re-presenting the world of intersubjective relations through "the key notion of incommunicability; no one point of view can encompass the whole situation because no one subject can understand the experience of others" (p. 102, emphasis in the original). She describes Joseph Zobel as "a skilled practitioner of the short story form," praising his "complex representation of the social hierarchies that structure village life" across a range of class and familial contexts. And her brilliant psychosocial and ethnohistorical reading of the complex plot lines and interpersonal relationships of Maryse Condés La Belle Créole shows clearly how complex patterns of doubled Freudian desire problematize "a stereotyped and melodramatic version of a historical past that bore no relation to present-day reality" (p. 132).

A chapter on the work of Michel Leiris clarifies the complex imbrication of ethnography and colonialism, emphasizing the ways in which "the (inter)subjective element in Leiris's ethnography" (p. 29) shows strong similarities to Glissant's thought in "the theme of contacts between cultures" (p. 25). And Britton's rich, in-depth analysis of René Ménil's thought demonstrates that the double consciousness of W.E.B. Du Bois "is linked to his view of the necessary 'doubleness' of Caribbean consciousness" (p. 45); similarly, she shows that Ménil is indebted to Althusser's conviction of the capacity of writing to define "its own representation of reality as ideological" (p. 47; emphasis in the original), and as this nuanced reading effectively points out, his approach, through its "commitment to political struggle" (p. 51), accomplishes a dialectic inscription of cultural identity which is "necessarily fluid and open-ended" (p. $5^{2}$ ).

A triumph of close reading and analytical interpretation, this volume will be indispensable to scholars of French Caribbean literature.

\author{
H. Adlai Murdoch \\ Department of Romance Studies, Tufts University \\ H.Murdoch@tufts.edu
}

